\title{
Interactions between oestradiol and epidermal growth factor in endometrial stromal proliferation and differentiation
}

\author{
S. J. Mellor and E. J. Thomas* \\ Department of Obstetrics and Gynaecology, University of Southampton, Princess Anne Hospital, \\ Coxford Road, Southampton SO16 5 YA, UK
}

\begin{abstract}
The relationship between oestradiol and epidermal growth factor (EGF) in the control of endometrial proliferation and differentiation in cultures of human endometrial stromal cells was investigated. Oestradiol at a concentration of $10 \mathrm{nmol} \mathrm{l}^{-1}$ increased the incorporation of both $\left[{ }^{3} \mathrm{H}\right]$ thymidine and $\left[{ }^{3} \mathrm{H}\right]$ leucine but the differences were significantly different from control only for $\left[{ }^{3} \mathrm{H}\right]$ leucine incorporation. Concentrations of $0.16,1.6$ and $16 \mathrm{nmol} \mathrm{EGF} 1^{-1}$ significantly increased both $\left[{ }^{3} \mathrm{H}\right]$ thymidine $(P<0.01)$ and $\left[{ }^{3} \mathrm{H}\right]$ leucine incorporation $(P<0.01)$. The pure steroidal antioestrogen, ICI 182,780, inhibited any increase in $\left[{ }^{3} \mathrm{H}\right]$ thymidine and $\left[{ }^{3} \mathrm{H}\right]$ leucine incorporation stimulated by oestradiol in endometrial stroma. The monoclonal antibody, ICR 16, directed against the EGF receptor did not inhibit the oestradiol action in stromal cells, indicating that, in this model system, oestradiol does not act by inducing synthesis or release of EGF. However, ICI 182,780 potently inhibited the incorporation of $\left[{ }^{3} \mathrm{H}\right]$ thymidine stimulated by EGF in endometrial stromal cells, suggesting interdependence between oestradiol and EGF in the control of endometrial stromal proliferation. Oestrogen-free conditioned medium from endometrial stromal cultures did not stimulate either $\left[{ }^{3} \mathrm{H}\right]$ thymidine or $\left[{ }^{3} \mathrm{H}\right]$ leucine incorporation, suggesting that oestradiol did not stimulate the secretion of a trophic factor from endometrial stromal cells.
\end{abstract}

\section{Introduction}

The precise mechanisms involved in endometrial proliferation have been studied intensely in recent years, owing to the emerging consensus that oestrogen may not act only through its receptor. Many workers have failed to demonstrate a proliferative response to oestrogen in endometrial cell cultures in vitro, of either epithelial cells or stromal cells (Casimiri et al., 1980; Fleming and Gurpide, 1982; Alkhalaf et al., 1991; Haining et al., 1991; Uchima et al., 1991), although oestrogen will cause proliferation of either epithelial cells or stromal cells under certain culture conditions (Gerschenson et al, 1981; Irwin et al., 1991; Olive et al., 1991). One potential candidate as the agent which controls endometrial proliferation is epidermal growth factor (EGF). Administration of EGF to ovariectomized mice induces uterine and vaginal growth equivalent to that in control mice given oestradiol, and this action of oestradiol is inhibited by an antibody directed against EGF (Nelson et al., 1991). In this model, EGF also induces the expression of lactoferrin, a major oestrogen-inducible secretory protein, in mice. EGF (Haining et al., 1991) and its receptor (EGF-R; Smith et al., 1991) have been identified in human endometrium. Studies have indicated that the concentrations of EGF (Gonzalez et al., 1984) and EGF-R (Bonaccorsi et al., 1989; Stancel et al., 1990; Taketani and Mizuno, 1991; Troche et al.,

${ }^{*}$ Correspondence.

Received 20 December 1994
1991) are regulated by oestrogen in the endometrium. Transforming growth factor $\alpha$ (TGF- $\alpha$ ) has also been shown to mediate oestrogen action in the mouse uterus (Nelson et al., 1992).

The aim of this study was to investigate further the relative roles of oestradiol and EGF in endometrial proliferation. Any possible interdependence between oestrogen and EGF in endometrial growth was examined using specific inhibitors of their action in a model system of cultured human endometrial stromal cells. Endometrial stromal cells were chosen because they are known to express oestrogen and EGF receptors, and because they yield an extremely pure population of cells, which facilitates experimental design and interpretation. The actions of oestradiol were inhibited by using the pure specific antioestrogen ICI 182,780 (Wakeling et al., 1991). ICR16, a monoclonal antibody directed against the EGF receptor (Modjtahedi et al., 1993), was used to inhibit EGF action. This strategy enabled examination of two further hypotheses. First, if oestrogen acts on the endometrium to release a trophic factor such as EGF, which then stimulates replication of endometrial stromal cells, then treatment of stromal cultures with ICI 182,780 should inhibit production of this factor and thus any proliferative effect of such a factor should be abolished. Second, if oestrogen causes endometrial growth indirectly via the action of EGF, then treatment of stromal cell cultures with the anti-EGF-R antibody should inhibit any actions of oestrogen. 


\section{Materials and Methods}

\section{Materials}

Human recombinant EGF was obtained from Boehringer Mannheim (Lewes). Collagenase type XI, insulin, oestradiol, Hepes, L-glutamine, thymidine and leucine were all obtained from Sigma (Poole). Percoll was obtained from Pharmacia (Milton Keynes). Hank's balanced salt solution without calcium, magnesium or phenol red and 10000 iu penicillin $\mathrm{ml}^{-1}-10000 \mu \mathrm{g}$ streptomycin $\mathrm{ml}^{-1}$ were obtained from Northumbria Biologicals Ltd (Cramlington). Dulbecco's modified Eagle's medium, Ham's nutrient mixture F12, amphotericin $B$ (fungizone), gentamycin and nonessential amino acids were obtained from Gibco (Paisley). A custom-made mixture of 1:1 DMEM:F12 without thymidine, leucine or phenol red was also supplied by Gibco. Charcoal-treated fetal calf serum was obtained from Imperial Laboratories (Andover). Trichloroacetic acid (TCA) was provided by BDH (Poole) and Optiscint HiSafe from Wallac (Milton Keynes). All other chemicals were obtained from either BDH or Sigma.

Methyl $\left[{ }^{3} \mathrm{H}\right]$ thymidine, $\mathrm{L}-(4,5)\left[{ }^{3} \mathrm{H}\right]$ leucine and the Biotrak EGF ELISA kit were all purchased from Amersham International (Amersham, Bucks).

ICI $\quad 182,780 \quad(7 \alpha[9-(4,4,5,5,5$-pentafluoropentylsulphinyl) nonyl]estra-1,3,5(10)-triene-3,17 $\beta$-diol) has potent and pure antioestrogenic activity both in vitro (Wakeling et al., 1991) and in vivo (Thomas et al., 1994). The rat monoclonal antibody, ICR16, inhibits EGF activity by blocking the receptor (Modjtahedi et al., 1993). The control antibody used was ALN/11/53, as described by Modjhedi et al. (1993).

\section{Tissue samples}

Endometrial biopsies were obtained from patients undergoing either hysterectomy or surgical procedures for benign gynaecological disorders using a Pipelle suction curette (Eurosurgical; Cranleigh). None of the patients was receiving any hormonal treatment before surgery, and the operations were performed for menorrhagia or fibroids. The phase of the menstrual cycle at which the specimens were obtained was determined by the date of the last menstrual period. Of the samples used in the experiments, $57 \%$ were from day 6 to day 14 of the cycle and the remaining $43 \%$ from day 15 to day 28 . Tissue samples were collected in Hank's balanced salt solution without calcium, magnesium or phenol red, supplemented with $20 \mathrm{mmol}$ Hepes $\mathrm{l}^{-1}, 100 \mathrm{iu}$ penicillin $\mathrm{ml}^{-1}, 100 \mu \mathrm{g}$ streptomycin $\mathrm{ml}^{-1}$ and $5 \mu \mathrm{g}$ amphotericin $\mathrm{B} \mathrm{ml}{ }^{-1}$ (medium A). Further processing of the tissue samples occurred in the cell culture laboratory.

All patients gave their consent to the collection of tissue specimens. Ethical permission for this study was granted by Southampton and South West Hampshire Health Authority/ University of Southampton Joint Ethics Committee.

\section{Isolation and culture of endometrial stromal cells}

Endometrial stromal cells uncontaminated with glandular epithelial cells were isolated using the method described by
Mellor and Thomas (1994). Endometrial tissue was minced and digested with $1 \mathrm{mg}$ collagenase type $\mathrm{XI} \mathrm{ml}{ }^{-1}$ until individual endometrial glands were released from the preparation. Undigested pieces of tissue and endometrial glands were removed from the digest by a two-step filtration procedure through $45 \mu \mathrm{m}$ and $10 \mu \mathrm{m}$ nylon meshes (Lockertex, Warrington). The filtrate was centrifuged (at $500 \mathrm{~g}$ for $15 \mathrm{~min}$ ) over $60 \%$ Percoll to remove contaminating red blood cells. After washing the cells contained in the band at the interface of the Percoll and medium A, cells were resuspended in 1:1 DMEM:F12 containing $20 \mathrm{mmol}$ Hepes $\mathrm{l}^{-1}, 100 \mu \mathrm{g}$ streptomycin $\mathrm{ml}^{-1}, 100 \mathrm{iu}$ penicillin $\mathrm{ml}^{-1}, 5 \mu \mathrm{g}$ amphotericin $\mathrm{B} \mathrm{ml} \mathrm{ml}^{-1}, 1 \%(\mathrm{v} / \mathrm{v})$ nonessential amino acids, $50 \mu \mathrm{g}$ gentamycin $\mathrm{ml}^{-1}, 10 \mathrm{mmol}$ L-glutamine $\mathrm{l}^{-1}, 10 \mu \mathrm{g}$ insulin $\mathrm{ml}^{-1}$ and $5 \%(\mathrm{v} / \mathrm{v})$ charcoaltreated fetal calf serum (medium C). After counting by haemocytometry, cells were plated out at a concentration of $1 \times 10^{5} \mathrm{ml}^{-1}$ in 24-well plates (Nunc, Paisley). The stromal cells were allowed to adhere overnight in a humid atmosphere of $95 \% \mathrm{CO}_{2}: 5 \% \mathrm{O}_{2}$ at $37^{\circ} \mathrm{C}$. On the following day, this medium was removed and replaced with the custom-made phenol red-free 1:1 DMEM:F12 containing all the additions listed above. Cells were incubated in this medium for a further 3 days until experiments began. The medium was replenished every 3 days.

\section{${ }^{3}$ H]thymidine and $\Gamma^{3}$ Hleucine incorporation studies}

All experiments were performed in phenol red-free medium C. Oestradiol and ICI 182,780 were dissolved in ethanol, and appropriate dilutions prepared in culture medium. The final concentration of ethanol in all wells was adjusted to $0.01 \%$ $(\mathrm{v} / \mathrm{v})$. Experiments were commenced on day 4 of culture. Stromal cells were incubated with the agent(s) of interest (oestradiol, ICI 182,780, EGF or anti-EGF-R antibody) for $48 \mathrm{~h}$. Experimental media are replaced after $24 \mathrm{~h}$. Methyl $\left[{ }^{3} \mathrm{H}\right]$ thymidine or $L-4,5-\left[{ }^{3} \mathrm{H}\right]$ leucine was added for the final $18 \mathrm{~h}$ of the experiment at a concentration of $5 \mu \mathrm{Ci} \mathrm{ml}^{-1}\left(185 \mathrm{kBq} \mathrm{ml}^{-1}\right)$. At the conclusion of the experiment, the medium was removed; the cells were washed in medium $\mathrm{A}$ and removed from the plates with $0.05 \%(\mathrm{v} / \mathrm{v})$ trypsin-0.02\% $(\mathrm{v} / \mathrm{v})$ EDTA and by scraping. The radioactive macromolecules were precipitated by the addition of TCA to a final concentration of $5 \%(\mathrm{w} / \mathrm{v})$ $\left({ }^{3} \mathrm{H}\right]$ thymidine experiments) or $10 \%(\mathrm{w} / \mathrm{v})\left(\left[{ }^{3} \mathrm{H}\right] \mathrm{leucine}\right.$ experiments). After at least $1 \mathrm{~h}$ at $4^{\circ} \mathrm{C}$, the precipitates were collected on Whatman GF/C filters (BDH) and air-dried. The liquid scintillant Optiscint HiSafe was added and the radioactivity on the filters determined by scintillation counting (LKB). For the ICR16 antibody experiments, the stromal cells were preincubated with the antibody for $2 \mathrm{~h}$ before to the addition of EGF.

\section{Preparation of conditioned media}

Cells were plated out in $75 \mathrm{~cm}^{2}$ flasks (Nunc) at an equivalent cell density to that used for the experiments in 24-well plates. The same experimental protocol as in the labelling studies described above was used for the preparation of conditioned media. Cells were incubated in phenol red-free medium $\mathrm{C}$ under the following experimental conditions: control (ethanolic vehicle alone), $10 \mathrm{nmol}$ oestradiol $\mathrm{l}^{-1}, 10 \mathrm{nmol}$ 
Table 1. Effect of various concentrations of oestradiol and epidermal growth factor (EGF) on $\left[{ }^{3} \mathrm{H}\right]$ thymidine and $\left[{ }^{3} \mathrm{H}\right]$ leucine incorporation in endometrial stromal cell cultures

\begin{tabular}{|c|c|c|c|c|c|}
\hline Parameter & $\begin{array}{l}\text { Oestradiol } \\
\left(\mathrm{nmol} \mathrm{I} \mathrm{I}^{-1}\right)\end{array}$ & $\begin{array}{l}\text { Percentage of } \\
\text { control (SEM) }\end{array}$ & $\begin{array}{c}\mathrm{EGF} \\
\left(\mathrm{nmol} \mathrm{l} \mathrm{l}^{-1}\right)\end{array}$ & $\begin{array}{r}\text { Perc } \\
\text { con }\end{array}$ & $\begin{array}{l}\text { entage of } \\
\text { trol (SEM) }\end{array}$ \\
\hline \multirow{4}{*}[{}^{3}\mathrm{H}]{ thymidine incorporation } & 0.01 & $75.6(10.9)$ & 0.16 & 248 & $(29)^{*}$ \\
\hline & 0.1 & $94 \quad(4.1)$ & 1.6 & 238 & $(29)^{* *}$ \\
\hline & 1 & $130.1(35)$ & 16 & 274 & $(48)^{* * *}$ \\
\hline & 10 & $129 \quad(19.7)$ & & & \\
\hline \multirow[t]{4}{*}[{}^{3}\mathrm{H}]{ leucine incorporation } & 0.01 & $(8.8)$ & 0.16 & 134.5 & $(4.6)$ \\
\hline & 0.1 & $107.5 \quad(5.8)$ & 1.6 & 142.2 & $(5)^{* *}$ \\
\hline & 1 & $101.4 \quad(3.3)$ & 16 & 133.9 & $(4)^{* *}$ \\
\hline & 10 & $111.7(6.2)^{*}$ & & & \\
\hline
\end{tabular}

Data are expressed as percentage of the control value (control $=100 \%$ ) and are a mean of four experiments for oestradiol and three for EGF.

${ }^{*} P<0.05,{ }^{* *} P<0.01,{ }^{* * *} P<0.001$.

oestradiol $1^{-1}$ plus $100 \mathrm{nmol}$ ICI $182,780 \mathrm{l}^{-1}$, or $100 \mathrm{nmol} \mathrm{ICl}$ $182,7801^{-1}$ alone. The media for each treatment were collected after 24 and $48 \mathrm{~h}$ and then pooled. Residual oestradiol and ICI 182,780, which might have interfered with the interpretation of experimental data, were removed from the conditioned media by ultrafiltration using Centriprep concentrators (Amicon, Stonehouse, Gloucestershire) with a membrane cut-off of $3 \mathrm{kDa}$. After ultrafiltration, the concentrate was diluted to the original volume using phenol red-free, insulinfree medium $C$ that contained only $1 \%(\mathrm{w} / \mathrm{v})$ charcoal-treated fetal calf serum, and filtered through $0.22 \mu \mathrm{m}$ filters. Oestradiol assay (Serono Diagnostics, Fleet) performed on the conditioned media that initially contained $10 \mathrm{nmol}$ oestradiol $\mathrm{I}^{-1}$ revealed that, after ultrafiltration, the concentration of oestradiol was $400 \mathrm{pmol} \mathrm{I}^{-\mathrm{I}}$, a concentration that was ineffective on $\left[{ }^{3} \mathrm{H}\right]$ thymidine or $\left[{ }^{3} \mathrm{H}\right]$ leucine incorporation in the assay system described here.

A small aliquot of each conditioned medium was taken for EGF assay. The remainder was applied to fresh stromal cell cultures for $\left[{ }^{3} \mathrm{H}\right]$ thymidine incorporation studies using the basic experimental protocol.

\section{EGF assay}

Aliquots of the conditioned media were assayed for EGF with the EGF Biotrak ELISA.

\section{Western blotting}

Endometrial stromal cells in $75 \mathrm{~cm}^{2}$ flasks were treated with $10 \mathrm{nmol}$ oestradiol $1^{-1}$ either alone or in combination with $100 \mathrm{nmol} \mathrm{ICI} 182,780 \mathrm{l}^{-1}$, as in the protocol described above, for $48 \mathrm{~h}$. At the end of the experiments, cells were removed by trypsinization and scraping and collected by centrifugation at $110 \mathrm{~g}$ for $5 \mathrm{~min}$. The approximate volume of the pellet was determined and an 8 times excess of Tris-EDTA-molybdate buffer $\left(10 \mathrm{mmol}\right.$ Tris $1^{-1}, 1.5 \mathrm{mmol}$ EDTA $1^{-1}, 5.0 \mathrm{mmol}$ sodium molybdate $1^{-1}$ ) containing $1 \mathrm{mmol}$ monothioglycerol $1^{-1}$ was added. After thorough vortex mixing, the tubes were centrifuged at $4^{\circ} \mathrm{C}$ for $20 \mathrm{~min}$ at $2500 \mathrm{~g}$. Cytosols were analysed by western blotting to detect the oestrogen receptor by S. Dauvois and M. G. Parker (Imperial Cancer Research Fund, London).

\section{Statistical analysis}

All the data were analysed statistically using Student's paired $t$ test.

\section{Results}

\section{Culture of endometrial stromal cells}

Characterization of endometrial stromal cells isolated using a two-step filtration method is discussed by Matthews et al. (1992). Filtration of the tissue digest through a $10 \mu \mathrm{m}$ filter results in preparations of stromal cells virtually uncontaminated with glandular epithelial cells. Cells were plated out in phenol red-containing medium $C$. After the cells had adhered to the plastic of the culture vessels (overnight), the cells were washed in medium $A$ and incubated in phenol red-free medium $C$. The brief period in which the cells were exposed to phenol red did not affect cellular responses to oestradiol, since cells spent a further 3 days in phenol red-free medium $C$. The stage of the menstrual cycle at which the cells were isolated did not appear to affect the experimental data, although the small numbers used in each experiment may have concealed differences.

\section{Effect of oestradiol and EGF on ${ }^{3}$ H]thymidine and ${ }^{3} \mathrm{H}$ lleucine incorporation in endometrial stromal cells in culture}

Table 1 shows that $10 \mathrm{nmol}$ oestradiol $\mathrm{I}^{-1}$ increased both $\left[{ }^{3} \mathrm{H}\right]$ thymidine and $\left[{ }^{3} \mathrm{H}\right]$ leucine incorporation, but that only the increase in $\left[{ }^{3} \mathrm{H}\right]$ leucine incorporation was statistically significant $(P=0.15$ and $P=0.04$, respectively). EGF significantly stimulated DNA and protein synthesis at both $1.6(P<0.01)$ and 


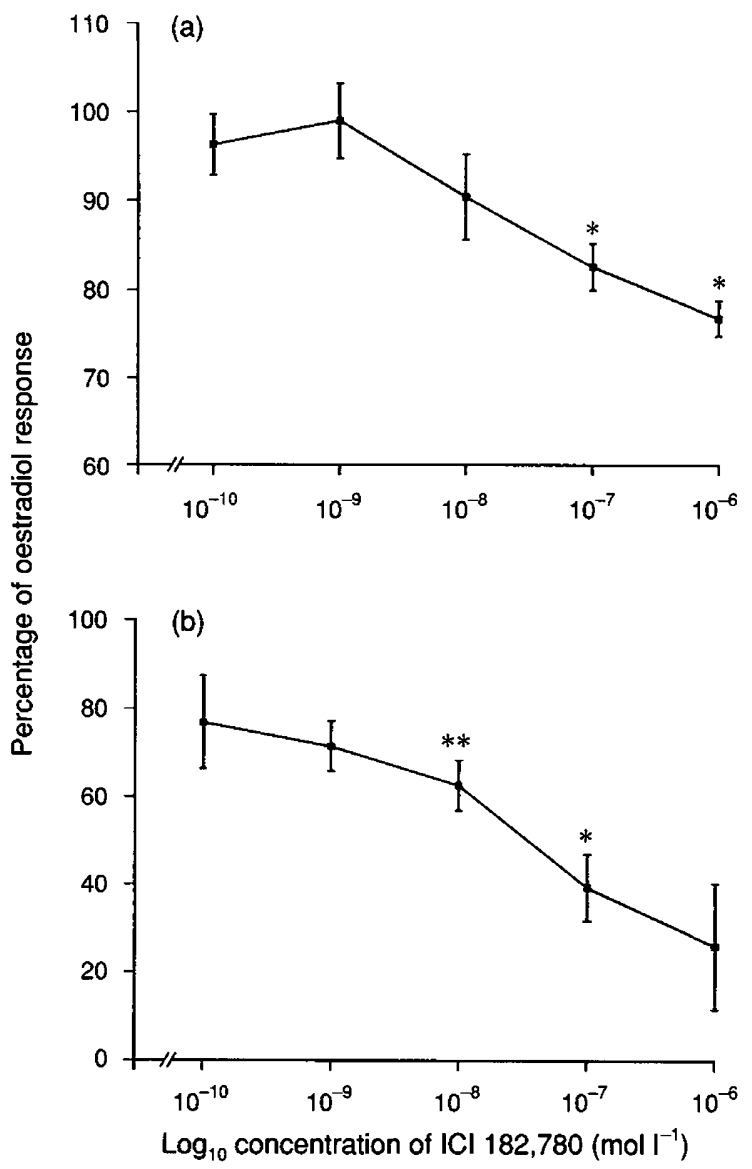

Fig. 1. Effect of various concentrations of ICI 182,780 and $10 \mathrm{nmol}$ oestradiol $\mathrm{I}^{-1}$ on (a) $\left[{ }^{3} \mathrm{H}\right]$ leucine and (b) $\left[{ }^{3} \mathrm{H}\right]$ thymidine incorporation in endometrial stromal cell cultures. Values are mean $( \pm$ SEM) and represent three experiments $\left({ }^{3} \mathrm{H}\right]$ thymidine) or six experiments ( $\left[{ }^{3} \mathrm{H}\right]$ leucine). ${ }^{*} P<0.05,{ }^{* *} P<0.01$ compared with $10 \mathrm{nmol}$ oestradiol $1^{-1}$ alone.

$16 \mathrm{nmol}^{-1}(P<0.01)$, but $0.16 \mathrm{nmol}$ EGF $1^{-1}$ augmented only $\left[{ }^{3} \mathrm{H}\right]$ thymidine incorporation $(P<0.05)$.

\section{Inhibition of oestradiol-stimulated $\left[^{3} \mathrm{H}\right]$ thymidine and $\left.\Gamma^{3} \mathrm{H}\right]$ leucine incorporation by ICI 182,780}

When stromal cells were incubated with various concentrations of ICI 182,780 in the absence of oestradiol, $\left[{ }^{3} \mathrm{H}\right]$ thymidine and $\left[{ }^{3} \mathrm{H}\right]$ leucine incorporation did not differ from control values. Co-incubation with various doses of ICI 182,780 inhibited any stimulation of $10 \mathrm{nmol}$ oestradiol $\mathrm{I}^{-1}$ on both $\left[{ }^{3} \mathrm{H}\right]$ leucine and $\left[{ }^{3} \mathrm{H}\right]$ thymidine incorporation (Fig. I). Furthermore, there was a suppression of this incorporation below control values, which was statistically significant at concentrations of ICI 182,780 of $100 \mathrm{nmol} \mathrm{l}^{-1}$ and $10 \mathrm{nmol} \mathrm{l}^{-1}$ for the $\left[^{3} \mathrm{H}\right]$ thymidine experiments and $1000 \mathrm{nmol}$ ICI $182,7801^{-1}$ for the $\left[{ }^{3} \mathrm{H}\right]$ leucine experiments $(P<0.05)$. Figure 2 is a western blot analysis for oestrogen receptors showing that oestrogen receptors are absent from stromal cells treated with vehicle alone, but are induced by treatment of cells with $10 \mathrm{nmol}$ oestradiol $\mathrm{l}^{-1}$ for $48 \mathrm{~h}$, estimated at $25 \mathrm{fmol}$ protein $\mathrm{mg}^{-1}$.
Fig. 2. Western blot of cytosolic extracts of human endometrial stromal cells and immunodetection of the oestrogen receptor. Track 1 , control cells; track $2,10 \mathrm{nmol}$ oestradiol $1^{-1}$; track $3,10 \mathrm{nmol}$ oestradiol $1^{-1}$ and $100 \mathrm{nmol}$ ICI 182,780 $1^{-1}$; track 4, $100 \mathrm{nmol} \mathrm{ICI}$ $182,780 \mathrm{1}^{-1}$; track 5 , positive control corresponding to approximately $200 \mathrm{fmol}$ oestrogen receptor $1^{-1}$.

This induction of the oestrogen receptor was completely blocked by co-incubation of $10 \mathrm{nmol}$ oestradiol $\mathrm{l}^{-1}$ and $100 \mathrm{nmol}$ ICI $182,780 \mathrm{1}^{-1}$. Administration of $100 \mathrm{nmol} \mathrm{ICI}$ $182,7801^{-1}$ alone did not induce expression of the oestrogen receptor.

\section{Co-incubation of EGF with the anti-EGF-R antibody ICR16}

Table 2 shows that $5 \mu \mathrm{g} \mathrm{ICR} 16 \mathrm{ml}^{-1}$ inhibited by $50 \%$ the incorporation of $\left[{ }^{3} \mathrm{H}\right]$ thymidine stimulated by $1.6 \mathrm{nmol}$ EGF $1^{-1}$ and that the response was completely abolished with $10 \mu \mathrm{g}$ ICR16 ml $\mathrm{ml}^{-1}$. Because of the large quantities of antibodies required, a limited number of control wells were included to conserve supplies. A concentration of $5 \mu \mathrm{g} \mathrm{ml}^{-1}$ of a control antibody in combination with $1.6 \mathrm{nmol} \mathrm{EGF} 1^{-1}$ did not diminish the response to $1.6 \mathrm{nmol} \mathrm{EGF} \mathrm{l}^{-1}$. However, $10 \mu \mathrm{g} \mathrm{ml}^{-1}$ of the control antibody decreased the amount of radioactivity to $50 \%$ of the control value. 
Table 2. Effect of the antibody ICR16 on EGF-induced $\left[{ }^{3} \mathrm{H}\right]$ thymidine incorporation in endometrial stromal cultures

$\left[{ }^{3} \mathrm{H}\right]$ thymidine incorporation: percentage of

Addition control (SEM) experimental protocol. ICI 182,780 inhibited EGF action in endometrial stromal cells (Fig. 3). All the concentrations of $\mathrm{ICI}$ 182,780 tested were effective at reducing the stimulation of $\left[{ }^{3} \mathrm{H}\right]$ thymidine incorporation into DNA by $1.6 \mathrm{nmol} \mathrm{EGF} \mathrm{l}^{-1}$ $(P<0.05)$. There was no significant reduction in EGF-induced stimulation of $\left[{ }^{3} \mathrm{H}\right]$ leucine incorporation by ICI 182,780 .

\section{Discussion}

This study describes a series of experiments carried out to clarify the interactions and interdependence between oestradiol and EGF in the endometrium by delineating their individual actions and interactive roles, using human endometrial stromal cells as a model. By using specific inhibitors of the action of oestradiol and EGF, the hypothesis that oestrogen causes growth and differentiation of the human endometrium by inducing the synthesis or release of the polypeptide growth factor, EGF, was tested.

In pure cultures of human endometrial stroma cells, $10 \mathrm{nmol}$ oestradiol $\mathrm{l}^{-1}$ had a small stimulatory effect on DNA and protein synthesis. However, in these cells, EGF was potently mitogenic. Western blotting demonstrated that oestradiol administration induced oestrogen receptor expression in the stromal cells, so it appears that the absence of a mitogenic response to oestradiol was not due to a deficiency in oestrogen receptors. Uchima et al. (1991) were unable to demonstrate a proliferative response to oestradiol in uterine epithelial cells despite the presence of functional oestrogen receptors. Other authors have reported the apparent dichotomy that oestrogen can induce protein synthesis or progesterone receptor expression, without a concomitant increase in cellular proliferation (Casimiri et al., 1980; Aronica and Katzenellenbogen, 1991; Uchima et al., 1991).

It was not possible to demonstrate that the activity of oestradiol in endometrial stromal cells was inhibited by an antibody directed against the EGF-R. Under the same experimental conditions in which the mitogenic activity of EGF was completely abolished, no inhibition of oestradiol action by the anti-EGF-R antibody was observed. Similarly, there was no evidence that the action of oestradiol induced synthesis or release of EGF, since EGF was not detected in conditioned media from stromal cells that had been treated with $10 \mathrm{nmol}$ oestradiol $1^{-1}$. If oestradiol acted through a cascade mechanism, then it might be expected that a small amount of EGF would have a large effect on endometrial growth. However, any EGF in the oestradiol-conditioned medium would have been present at concentrations of less than $0.2 \mathrm{pg} \mathrm{ml}^{-1}$, the limit of sensitivity of the kit used. Since the conditioned medium had no effect on $\left[{ }^{3} \mathrm{H}\right]$ thymidine incorporation when applied to fresh stromal cell cultures, either EGF can cause proliferation only at concentrations of greater than $0.2 \mathrm{pg} \mathrm{ml} \mathrm{ml}^{-1}$ or no suitable stimulatory growth factors were induced by oestradiol treatment under these experimental conditions.

The experiments performed with ICI 182,780 alone confirm the classification of $\mathrm{ICI} 182,780$ as a pure steroidal antioestrogen (Wakeling et al., 1989, 1991; Dukes et al., 1992, 1993; Wade et al., 1993). ICI 182,780 alone in stromal cell culture did not demonstrate any oestrogenic effect and inhibited

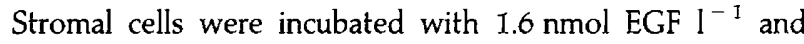
various concentrations of ICI 182,780 using the standard 
Table 3. Effect of co-incubating endometrial stromal cells with $10 \mathrm{nmol}$ oestradiol $\mathrm{I}^{-1}$ and the antibody ICR 16

\begin{tabular}{|c|c|c|}
\hline Addition & $\begin{array}{c}{\left[{ }^{3} \mathrm{H}\right] \text { thymidine: } \% \text { of }} \\
\text { control (SEM) }\end{array}$ & $\begin{array}{c}{\left[{ }^{3} \mathrm{H}\right] \text { leucine: } \% \text { of }} \\
\text { control (SEM) }\end{array}$ \\
\hline $10 \mathrm{nmol}$ oestradiol $\mathrm{l}^{-1}$ & $121.3(17.3)$ & $132(6.2)^{*}$ \\
\hline $10 \mathrm{nmol}$ oestradiol $\mathrm{l}^{-1} / 10 \mu \mathrm{g} \mathrm{ICR} 16 \mathrm{ml}^{-1}$ & $115 \quad(9.2)$ & $125.8(4.0)^{*}$ \\
\hline Vehicle/10 $\mu \mathrm{g}$ ICR $16 \mathrm{ml}^{-1}$ & $76.9(13.5)$ & $107 \quad(4.5)$ \\
\hline $10 \mathrm{nmol}$ oestradiol $1^{-1} / 10 \mu \mathrm{g}$ control antibody $\mathrm{ml}^{-1}$ & $102(14.4)$ & $(6.4)^{*}$ \\
\hline Vehicle/10 $\mu \mathrm{g}$ control antibody $\mathrm{ml}^{-1}$ & $80.3(15.3)$ & $113(7.5)$ \\
\hline
\end{tabular}

Values are expressed as percentage of the control value (control $=100 \%$ ) and are means of three experiments, each performed in quadruplicate. ${ }^{*} p<0.02$.

Table 4. Effect of conditioned media (CM) from various sources on $\left[{ }^{3} \mathrm{H}\right]$ thymidine incorporation in endometrial stromal cells

\begin{tabular}{|c|c|}
\hline Source of conditioned medium & $\begin{array}{c}{\left[{ }^{3} \mathrm{H}\right] \text { thymidine incorporation: }} \\
\% \text { of control (SEM) }\end{array}$ \\
\hline \multicolumn{2}{|l|}{ CM from cells treated with } \\
\hline \multicolumn{2}{|l|}{ CM from cells treated with } \\
\hline $100 \mathrm{nmol} \mathrm{ICI} 182,7891^{-1}$ & $79.9 \quad(3.0)$ \\
\hline \multicolumn{2}{|l|}{$\mathrm{CM}$ from cells treated with } \\
\hline $100 \mathrm{nmol} \mathrm{ICI} 182,780 \mathrm{I}^{-1}$ & $97.5 \quad(9.5)$ \\
\hline
\end{tabular}

Values are means ( \pm SEM) of three experiments. Data are expressed as percentages of the control value (control $=100 \%$ ). No value was significantly different from the control.

oestradiol-stimulated $\left[{ }^{3} \mathrm{H}\right]$ thymidine or $\left[{ }^{3} \mathrm{H}\right]$ leucine incorporation, nor did it induce expression of the oestrogen receptor. Potent anti-oestrogenic activity of ICI 182,780 in vivo on endometrial proliferation in premenopausal women was reported by Thomas et al. (1994).

When $1.6 \mathrm{nmol}$ EGF $1^{-1}$ was incubated with various concentrations of ICI 182,780, it was found that ICI 182,780 profoundly inhibited EGF-induced $\left[{ }^{3} \mathrm{H}\right]$ thymidine but not $\left[{ }^{3} \mathrm{H}\right]$ leucine incorporation. This compares with the EGFanti-EGF-R antibody experiments, in which the anti-EGF-R antibody did not markedly inhibit protein synthesis. Such interactions between antioestrogens and growth factors have been noted previously. Proliferation of breast cancer MCF-7 cells induced by insulin or EGF is inhibited by 4-hydroxytamoxifen (Vignon et al., 1987). ICI 164,384 inhibits the proliferative action of both IGF-I and transforming growth factor $\alpha$ in MCF-7 cells, and is more effective at blocking MCF-7 growth than 4-hydroxytamoxifen (Wakeling et al., 1989). The EGFand IGF-I-induction of pS2 and cathepsin D mRNAs in MCF-7 cells is inhibited by ICI 164,384 (Chalbos et al., 1993). Progesterone receptors are induced by EGF, but not by other growth factors, and this effect is inhibited by 4-hydroxytamoxifen (Sumida and Pasqualini, 1989). ICI 164,384 inhibits EGF- and oestradiol-stimulated transcriptional activation in oestrogen receptor-transfected Ishikawa human endometrial adenocarcinoma cells (Ignar-Trowbridge et al.,

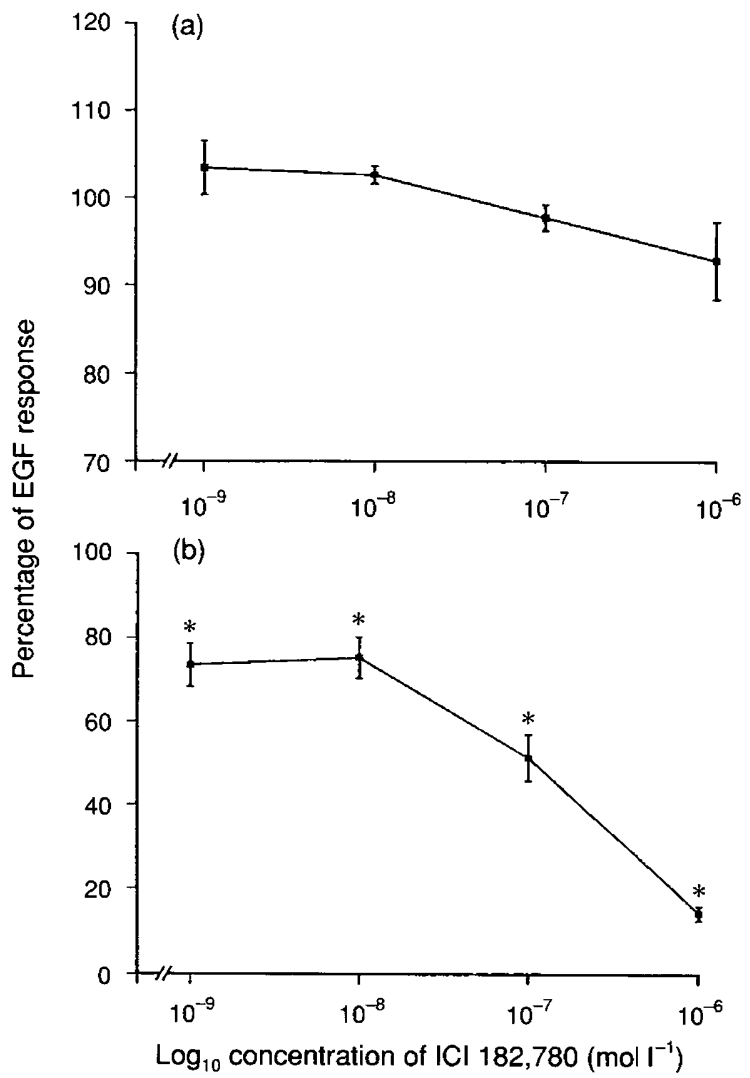

Fig. 3. Effect of co-incubation of $1.6 \mathrm{nmol}$ EGF $1^{-1}$ with various concentrations of ICI 182,780 on (a) $\left[{ }^{3} \mathrm{H}\right]$ leucine and (b) $\left[{ }^{3} \mathrm{H}\right]$ thymidine incorporation in endometrial stromal cultures. The data are expressed as means ( \pm SEM) of percentages of the EGF response alone $(100 \%)$. $* P<0.05$.

1993). ICI 164,384 also blocks EGF-induced uterine growth and diminishes EGF-induced phosphatidylinositol lipid turnover in ovariectomized mice (lgnar-Trowbridge et al, 1992). The absence of inhibition of EGF-induced protein synthesis by ICI 182,780 in human endometrial stroma cells is interesting in view of the failure of ICI 164,384 to inhibit phosphatidylinositol lipid turnover completely (Ignar-Trowbridge et al., 1992).

The antiproliferative effect of antioestrogens on growth factors appears to be mediated via the oestrogen receptor. In 
MCF-7 cells, there is a strong correlation between the growth factor-induced antiproliferative activity and the affinity of several non-steroidal antioestrogens for the oestrogen receptor (Vignon et al., 1987). In this model system, oestradiol can counter the anti-insulin effect of 4-hydroxytamoxifen. Furthermore, in a breast cancer cell line that is oestrogen receptornegative, EGF- and insulin-induced growth is not inhibited by 4-hydroxytamoxifen (Vignon et al., 1987). Inhibition of IGF-I induced pS2 and cathepsin D mRNA expression is oestrogen receptor specific (Chalbos et al., 1993). In the ovariectomized mouse model, EGF can mimic the action of oestrogen by causing enhanced nuclear localization of the oestrogen receptor, and the nuclear oestrogen receptor from EGF-treated mice forms similar complexes with the oestrogen response element to those from diethylstilboestrol-treated mice (IgnarTrowbridge et al., 1992). Induction of transcriptional activation of the oestrogen response element by EGF and inhibition of this phenomenon by ICI 164,384 are dependent on both the oestrogen receptor and the EGF-R (Ignar-Trowbridge et al., 1993).

If these observations are extended to the present study, then the inhibition by ICI 182,780 of EGF-induced proliferation of endometrial stromal cells may also be mediated via the oestrogen receptor. How this is achieved is not clear. The oestrogen receptor can bind to DNA in the absence of ligand (Reese and Katzenellenbogen, 1992) and also when ICI 164,384 is bound to the oestrogen receptor (Gibson et al., 1991; Reese and Katzenellenbogen, 1992). Binding of the oestrogen receptor to the DNA is insufficient to cause gene transcription (Reese and Katzenellenbogen, 1992), so it may be that an endpoint of EGF-R signal transduction is an alteration in the oestrogen receptor such that it can bind to the oestrogen response element and lead to gene transcription. EGF is known to increase the concentration of nuclear oestrogen receptor and to promote the formation of a nuclear oestrogen receptor species thought previously to be induced by oestradiol (IgnarTrowbridge et al., 1992), and it may be that these two events are either a consequence of an alteration of the oestrogen receptor or occur before binding of the oestrogen receptor to the oestrogen response element.

Targets of gene transcription as a result of oestradiol and EGF action may include the cellular oncogenes such as c-fos, $c-j u n$ and c-myc. EGF induces c-jun, $c-f o s$ and jun-B mRNAS in MCF-7 breast cancer cells (Davidson et al., 1993). In rat uteris, c-myc, c-fos, c-jun, jun B and jun D expression are all increased by oestradiol treatment (Murphy et al., 1987; Stancel et al., 1991; Chiappetta et al., 1992). In uterine epithelial cells, oestradiol, EGF and insulin stimulates c-fos expression in combination, but not separately (Jouvenot $e t$ al., 1990). Potential oestrogen response elements have been identified in the c-fos oncogene (Hyder et al., 1991) and c-myc (Dubik and Shiu, 1992). Since Fos-Jun and Jun-Jun dimers act as transcriptional regulators, those proto-oncogenes with upstream oestrogen responsive elements may be inhibited by ICI 182,780, where the ICI 182,780 is inhibiting oestradiol or EGF action. Specificity of oestradiol or EGF or other growth factor action may result from differential stimulation of cellular oncogenes by these factors, such that the response to individual stimuli may depend on whether the target genes activated are stimulated to transcribe by Fos-Jun or Jun-Jun. Additionally,
Fos and Jun may act in concert with the oestrogen receptor to regulate transcription of hormone-sensitive genes (Gaub et al., 1990).

The various signal transduction pathways of EGF action may explain why no inhibition of protein synthesis by the anti-EGF-R antibody, ICR16, was observed. It may be that the induction of cellular proliferation and cellular protein synthesis are caused by two different signal transduction mechanisms and that, although the ICR16 antibody blocked the transduction pathway leading to cellular proliferation, the antibody may not be able to block transduction by the EGF-R of the pathway resulting in increased protein synthesis. This may also explain why ICI 182,780 failed to inhibit EGF-induced protein synthesis. The pathway resulting in increased protein synthesis by EGF may not involve the oestrogen receptor and the oestrogen response element, but occur via another route. This would explain the observation that ICI 164,384 fails to completely block phosphatidylinositol lipid turnover induced by EGF (Ignar-Trowbridge et al., 1992).

Although release of EGF could not be demonstrated, it is possible that oestradiol may increase expression of the EGF-R (Bonaccorsi et al., 1989; Stancel et al., 1990; Taketani and Mizuno, 1991; Troche et al., 1991). The growth factor, transforming growth factor $\beta$, has growth inhibitory effects, and synthesis of this inhibitory factor is strongly induced by treatment of MCF-7 cells with 4-hydroxytamoxifen (Knabbe et al., 1987). ICI 182,780 inhibits insulin-like growth factor I (IGF-I)-induced MCF-7 cells proliferation and increases concentrations of an IGF-binding protein (Pratt and Pollak, 1993), possibly resulting in decreased availability of IGF-II. The mechanisms of action of oestradiol and ICI 182,780 and other antioestrogens may, therefore, involve a balance between modulation of the concentrations of growthpromoting growth factors, inhibitory growth factors, and factors regulating the binding, uptake or availability of these growth factors.

In conclusion, EGF was shown to be more mitogenic in cultured endometrial stromal cells than is oestradiol. The pure steroidal antioestrogen, $\mathrm{ICl} 182,780$ was an effective inhibitor of oestrogen-stimulated growth and differentiation in human endometrial stromal cells. No evidence in favour of the hypothesis that oestradiol causes endometrial growth by causing synthesis or release of EGF was found. Rather, the proliferative action of EGF in endometrium appeared to be mediated via the oestrogen receptor since EGF-stimulated mitogenesis was inhibited by the oestrogen receptor antagonist, ICI 182,780. EGF-mediated protein synthesis appeared to occur by an oestrogen receptor-independent mechanism.

S. J. Mellor was supported by WellBeing, with additional consumable support from the Royal Society. The authors thank M. Barron and N. Thomas for collecting the tissue, M. Parker and S. Dauvois (Imperial Cancer Research Fund, London) for performing western blotting analysis, C. J. Dean and H. Modjtahedi (Institute of Cancer Research, Surrey) for providing the EGF antibody and the control antibody, and A. Wakeling (Zeneca Pharmaceuticals) for providing both ICI 182,780 and advice. Finally, the authors thank P. Walton and Zeneca Pharmaceuticals for providing initial support for S. J. Mellor. 


\section{References}

Alkhalaf M, Propper AY and Adessi GL (1991) Proliferation of guinea-pig uterine epithelial cells in serum-free culture conditions: effect of $17 \beta$ estradiol, epidermal growth factor and insulin Joumal of Steroid Biochemistry and Molecular Biology 38 345-350

Aronica SM and Katzenellenbogen BS (1991) Progesterone receptor regulation in uterine cells: stimulation by estrogen, cyclic adenosine $3^{\prime}, 5^{\prime}$ monophosphate and insulin-like growth factor I and suppression by antioestrogens and protein kinase inhibitors Endocrinology 128 2045-2052

Bonaccorsi G, Pansini F, Segala V, Bagni B, Bergamini CM and Mollica G (1989) Modification of number and of affinity of endometrial EGF receptors during the menstrual cycle European Journal of Obstetrics and Gynaecology and Reproductive Biology 33 177-182

Casimiri V, Rath NC, Parvez H and Psychoyos A (1980) Effect of sex steroids on rat endometrial epithelium and stroma cultured separately Journal of Steroid Biochemistry 12 293-298

Chalbos D, Philips A, Galtier F and Rochefort H (1993) Synthetic antiestrogens modulate induction of $\mathrm{pS} 2$ and cathepsin-D messenger ribonucleic acid by growth factors and adenosine $3^{\prime}, 5^{\prime}$-monophosphate in MCF-7 cells Endocrinology 133 571-576

Chiappetta C, Kirkland JL, Loose-Mitchell DS, Murthy L and Stancel GM (1992) Estrogen regulates expression of the jun family of proto-oncogenes in the uterus Journal of Steroid Biochemistry and Molecular Biology 41 113-123

Davidson NE, Prestigiacomo LJ and Hahm HA (1993) Induction of jun gene family members by transforming growth factor $\alpha$ but not $17 \beta$-estradiol in human breast cancer cells Cancer Research 53 291-297

Dubik D and Shiu RPC (1992) Mechanism of oestrogen activation of c-myc oncogene expression Oncogene 7 1587-1594

Dukes M, Miller D, Wakeling AE and Waterton JC (1992) Antiuterotrophic effects of a pure antioestrogen, ICl 182,780: magnetic resonance imaging of the uterus in ovariectomized monkeys Journal of Endocrinology 135 239-247

Dukes M, Waterton JC and Wakeling AE (1993) Antiuterotrophic effects of the pure antioestrogen ICI 182,780 in adult female monkeys (Macaca nemestrina): quantitative magnetic resonance imaging Journal of Endocrinology 138 203-209

Fleming H and Gurpide E (1982) Growth characteristics of primary cultures of stromal cells from human endometrium Journal of Steroid Biochemistry 16 $717-720$

Gaub M-P, Bellard M, Scheuer I, Chambon P and Sassone-Corsi P (1990) Activation of the ovalbumin gene by the oestrogen receptor involves the Fos-Jun complex Cell 63 1267-1276

Gerschenson LE, Depaoli JR and Murai JT (1981) Inhibition of estrogen-induced proliferation of cultured rabbit uterine epithelial cells by a cell densitydependent factor produced by the same cells Journal of Steroid Biochemistry 14 959-969

Gibson MK, Nemmers LA, Beckman WC, Jr, Davis VL, Curtis SW and Korach KS (1991) The mechanism of ICl 164,384 antiestrogenicity involves rapid loss of estrogen receptor in uterine tissue Endocrinology 129 2000-2010

Gonzalez F, Lakshmanan J, Hoath S and Fisher DA (1984) Effect of oestradiol-17 $\beta$ on uterine epidermal growth factor concentration in immature mice Acta Endocrinologica $105425-428$

Haining REB, Cameron IT, van Papendorp C, Davenport AP, Prentice A, Thomas EJ and Smith SK (1991) Epidermal growth factor in human endometrium: proliferative effects in culture and immunocytochemical localization in normal and endometriotic tissues Human Reproduction 6 1200-1205

Hyder SM, Stancel GM and Loose-Mitchell DS (1991) Presence of an estradiol response region in the mouse c-fos oncogene Steroids 56 498-504

Ignar-Trowbridge DM, Nelson KG, Bidwell MC, Curtis SW, Washburn TF, McLachlan JA and Korach KS (1992) Coupling of dual signalling pathways: epidermal growth factor action involves the estrogen receptor Proceedings of the National Academy of Sciences, USA 89 4658-4662

Ignar-Trowbridge DM, Teng CT, Ross KA, Parker MG, Korach KS and McLachlan JA (1993) Peptide growth factors elicit estrogen receptor-dependent transcriptional activation of an estrogen-responsive element Molecular Endocrinology 7 992-998

Irwin JC, Utian WH and Eckert RL (1991) Sex steroids and growth factors differentially regulate the growth and differentiation of cultured human endometrial stromal cells Endocrinology 129 2385-2392

Jouvenot M, Pellerin I, Alkhalaf M, Marechal G, Royez M and Adessi GL (1990) Effects of $17 \beta$-estradiol and growth factors on c-fos gene expression in endometrial epithelial cells in primary culture Molecular and Cellular Endocrinology 72 149-157
Knabbe C, Lippman ME, Wakefield LM, Flanders KC, Kasid A, Derynck R and Dickson RB (1987) Evidence that transforming growth factor- $\beta$ is a hormonally regulated negative growth factor in human breast cancer cells Cell $\mathbf{4 8}$ $417-428$

Matthews CJ, Redfern CPF, Hirst BH and Thomas EJ (1992) Characterization of human purified epithelial and stromal cells from endometrium and endometriosis in tissue culture Fertility and Sterility $\mathbf{5 7}$ 990-997

Mellor SJ and Thomas EJ (1994) The actions of estradiol and epidermal growth factor in endometrial and endometriotic stroma in vitro Fertility and Sterility 62 507-513

Modjtahedi H, Styles JM and Dean CJ (1993) The human EGF receptor as a target for cancer therapy - six new rat MABs against the receptor on the breast carcinoma MDA-MB 468 British Journal of Cancer 67 247-253

Murphy LJ, Murphy LC and Freisen HG (1987) Oestrogen induction of n-myc and c-myc proto-oncogene expression in the rat uterus Endocrinology 120 1882-1888

Nelson KG, Takahashi T, Bossert NL, Walmer DK and McLachlan JA (1991) Epidermal growth factor replaces estrogen in the stimulation of female genital-tract growth and differentiation Proceedings of the National Academy of Sciences, USA 88 2I-25

Nelson KG, Takahashi T, Lee DC, Luetteke NC, Bossert NL, Ross K, Eitzman BE and McLachlan JA (1992) Transforming growth factor- $\alpha$ is a potential mediator of estrogen action in the mouse uterus Endocrinology 131 1657-1664

Olive DL, Montoya I, Riehl RM and Schenken RS (1991) Macrophageconditioned media enhance endometrial stromal cell proliferation in vitro American Journal of Obstetrics and Gynecology 164 953-958

Pratt SE and Pollak MN (1993) Estrogen and antiestrogen modulation of MCF 7 human breast cancer cell proliferation is associated with specific alterations in accumulation of insulin-like growth factor-binding proteins in conditioned media Cancer Research 53 5193-5198

Reese JC and Katzenellenbogen BS (1992) Examination of the DNA-binding ability of estrogen receptor in whole cells: implications for hormoneindependent transactivation and the actions of antiestrogens Molecular and Cellular Biology 12 4531-4538

Smith K, LeJeune S, Harris AH and Rees MCP (1991) Epidermal growth factor receptor in human uterine tissues Human Reproduction 6 619-622

Stancel GM, Chiappetta C, Gardner RM, Kirkland JL, Lin TA, Lingham RB, Loose-Mitchell DS, Mukku VR and Orengo CA (1990) Regulation of the uterine epidermal growth factor receptor by estrogen. In Molecular Endocrinology and Steroid Hormone Action pp 213-226 Ed. B Sato. AR Liss, New York

Stancel GM, Chiappetta C, Gardner RM, Hyder SM, Kirkland JL, Lin TH, Lingham RB, Loose-Mitchell DS, Mukku VR and Orengo CA (1991) Interactions of estrogens, proto-oncogenes and growth factors. In Cellular Signals Controlling Ulerine Function pp 49-61 Ed. LA Lavia. Plenum Press, New York

Sumida C and Pasqualini JR (1989) Antiestrogens antagonize the stimulatory effect of epidermal growth factor on the induction of progesterone receptor in fetal uterine cells in culture Endocrinology 124 591-597

Taketani $Y$ and Mizuno M (1991) Evidence for direct regulation of epidermal growth factor receptors by steroid hormones in human endometrial cells Human Reproduction 6 1365-1369

Thomas EJ, Walton PL, Thomas NM and Dowsett M (1994) The effects of ICI 182,780 , a pure anti-oestrogen, on the hypothalamic-pituitary-gonadal axis and on endometrial proliferation in pre-menopausal women Human Reproduction 9 1991-1996

Troche V, O'Connor DM and Schaudies RP (1991) Measurement of human epidermal growth factor receptor in the endometrium during the menstrual cycle American Journal of Obstetrics and Gynaecology 165 1499-1503

Uchima F-DA, Edery M, Iguchi T and Bern HA (1991) Growth of mouse endometrial luminal epithelial cells in vitro: functional integrity of the oestrogen receptor system and failure of oestrogen to induce proliferation Journal of Endocrinology 128 115-120

Vignon F, Bouton M-M and Rochefort H (1987) Antioestrogens inhibit the mitogenic effect of growth factors on breast cancer cells in the total absence of oestrogens Biochemical and Biophysical Research Communications 146 1502-1508

Wade GN, Blaustein JD, Gray JM and Meredith JM (1993) ICI 182,780: a pure antioestrogen that affects behaviours and energy balance in rats without acting in the brain American Journal of Physiology 265 R1392-R1398

Wakeling AE, Newboult E and Peters SW (1989) Effects of antioestrogens on the proliferation of MCF-7 human breast cancer cells journal of Molecular Endocrinology 2 225-234

Wakeling AE, Dukes $M$ and Bowler J (1991) A potent specific pure antioestrogen with clinical potential Cancer Research 51 3867-3873 